\title{
Common Problems Encountered by Selected Cooperatives in Cabanatuan City: Basis for Intervention Formulation
}

\author{
Mercy V. Torres
}

College of Management and Business Technology, Nueva Ecija University of Science and Technology, Philippines

\begin{abstract}
This study aims to determine the common problems encountered by selected cooperatives in Cabanatuan City. The researcher used the descriptive research method in this study. The study revealed that the majority of the respondents are 41-50 years old, married and most of them were from Kalikid and Aduas Cabanatuan City. Members' trust to the cooperatives was the top problem that challenges the operations and management of the cooperatives.
\end{abstract}

Keywords-Cooperatives, Cabanatuan City, Intervention.

\section{INTRODUCTION}

"Alone we can do a little, Together we can do so much" it is a quotation by Helen Keller, a perfect on cooperatives. Now what is cooperative? In the book it's definition is, it is a duly registered association of person with a common bond of interest who have voluntarily joined together to achieve a lawful common social or economic end, making equitable contributions to the capital required and accepting the fair share of the risk and benefits of the undertaking in accordance with universally accepted cooperative principles.

The objective of this organization is great. But the sad truth is that organizing a cooperative takes time and even problems suddenly arises. Cooperative is not exempted to risks and problems. These problems may be internal and external. Internal problems includes problems arises inside the cooperatives. For examples: a group of members decide to withdraw the memberships. Or, the member claims their property rights often describe "residual claimants" as being the beneficiaries of joint action whether it is in an investor-owned firm or a cooperative. Some member's loans remained unpaid for a long period of time. Hidden and untraceable corruption inside the cooperative and poor management. In the externals factors these include problems such as: Environmental calamities, pollutions, global warming, Technological, and Economical. These are the problems in which the management has no control to the changes but to go to the flow. If these problems were not be able to be solved by the management it may cause the cooperative to fade. Lastly, organizing cooperative is one of the measures taken by the government to help the people in improving their lives

\section{OBJECTIVES}

The researcher becomes aware of what is the current status of cooperatives in Cabanatuan City for it seems to be unnoticeable these days. For this reason the researcher selected of the existing cooperative in Cabanatuan City which has certificate of good standing and is operating at Cabanatuan City. This study aims to:

1. Describe the profile of the respondents

2. Determine the problems encountered by cooperatives

3. Propose intervention for the common problems encountered by selected cooperatives in Cabanatuan City.

\section{METHODOLOGY}

The researcher used the descriptive research method in this study. Questionnaire was utilized as survey instrument to gather pertinent data in order to assess the common problems encountered by selected cooperatives in Cabanatuan City. 


\section{RESULTS AND DISCUSSION}

\section{Profile of the respondents}

Table.1: Distribution of Respondents According to Gender

\begin{tabular}{|l|c|c|}
\hline \multicolumn{1}{|c|}{ Gender } & Frequency & Percentage \\
\hline Male & 96 & $64 \%$ \\
\hline Female & 54 & $36 \%$ \\
\hline Total & 150 & $100 \%$ \\
\hline
\end{tabular}

Table 1 shows that majority of the respondents are male $(64 \%)$ over the female respondents $(36 \%)$. It can be realized that most of the members are represented by the head of the family.

Table.2: Distribution of Respondents According to Age

\begin{tabular}{|l|c|c|}
\hline \multicolumn{1}{|c|}{ Age } & Frequency & Percentage \\
\hline $20-30$ & 11 & $7.33 \%$ \\
\hline $31-40$ & 47 & $31.33 \%$ \\
\hline $41-50$ & 67 & $44.67 \%$ \\
\hline $51-60$ & 25 & $16.67 \%$ \\
\hline Total & $\mathbf{1 5 0}$ & $\mathbf{1 0 0 \%}$ \\
\hline
\end{tabular}

Table 2 shows that the majority of the respondents have an age of 41-50 years old which is in $44 \%$ and the lowest age is $20-30$ years old which is only $7.33 \%$. it can be denoted that members joining cooperatives are in their adult stage where the sense of maturity and responsibility is more evident.

Table.3: Distribution of the Respondents According to their Years in the Cooperatives

\begin{tabular}{|l|c|c|}
\hline $\begin{array}{c}\text { Years in the } \\
\text { Cooperative }\end{array}$ & Frequency & Percentage \\
\hline 1-2 years & 43 & $28.67 \%$ \\
\hline 3-4 years & 83 & $55.33 \%$ \\
\hline 5-6 years & 9 & $10 \%$ \\
\hline $\begin{array}{l}\text { More than 6 } \\
\text { years }\end{array}$ & $\mathbf{1 5 0}$ & $\mathbf{1 0 0 \%}$ \\
\hline TOTAL & & \\
\hline
\end{tabular}

Table 3 shows that 83 or $55.33 \%$ of the respondents are in the cooperatives for 3-4 years now. Whereas, only 9 or $6 \%$ of the respondents are in the cooperatives for more than 6 years.

\section{Common Problems Encountered by Selected Cooperatives in Cabanatuan City.}

Table.5: Common Problems Encountered by Selected Cooperatives in Cabanatuan City

\begin{tabular}{|c|c|c|}
\hline Problems & $\begin{array}{l}\text { Weighted } \\
\text { Mean }\end{array}$ & Rank \\
\hline $\begin{array}{l}\text { 1. Poor communication to the } \\
\text { members }\end{array}$ & 2.07 & 6 \\
\hline $\begin{array}{l}\text { 2. Unreasonable and untraceable } \\
\text { expenses }\end{array}$ & 2 & 7 \\
\hline $\begin{array}{l}\text { 3. Many loans remain unpaid for a } \\
\text { long time }\end{array}$ & 2.31 & 2 \\
\hline $\begin{array}{l}\text { 4. Lack of enough capital for } \\
\text { operations }\end{array}$ & 2.23 & 5 \\
\hline $\begin{array}{l}\text { 5. Some members claim to much } \\
\text { from the co-op }\end{array}$ & 1.99 & 8 \\
\hline $\begin{array}{l}\text { 6. Poor performance of the } \\
\text { management }\end{array}$ & 1.75 & 10 \\
\hline $\begin{array}{l}\text { 7. Members are questioning the } \\
\text { capabilities of the management }\end{array}$ & 2.37 & 1 \\
\hline $\begin{array}{l}\text { 8. A group of members is } \\
\text { withdrawing their memberships }\end{array}$ & 1.95 & 9 \\
\hline $\begin{array}{l}\text { 9. Some members of the } \\
\text { management are incompetent }\end{array}$ & 2.15 & 4 \\
\hline $\begin{array}{l}\text { 10. Some members has a low } \\
\text { patronage and support to the } \\
\text { cooperative }\end{array}$ & 2.17 & 3 \\
\hline
\end{tabular}

Table 4 presents the frequency, weighted mean, ranking or responses of respondents on the Common Problems Encountered by Selected Cooperatives in Cabanatuan City.

3. Proposed Intervention on Common Problems Encountered by Selected Cooperatives in Cabanatuan City.

Table.5: Proposed Intervention on Common Problems Encountered by Selected Cooperatives in Cabanatuan City

\begin{tabular}{|l|l|}
\hline \multicolumn{1}{|c|}{$\begin{array}{l}\text { Intervention } \\
\text { Formulation }\end{array}$} & \multicolumn{1}{c|}{ Goal } \\
\hline $\begin{array}{l}\text { Capacity building of } \\
\text { cooperative } \\
\text { development } \\
\text { department staff in } \\
\text { monitoring, } \\
\text { supervision and }\end{array}$ & $\begin{array}{l}\text { Support development of safe } \\
\text { and sound SACCOs for the } \\
\text { benefit of members and } \\
\text { monetary stability }\end{array}$ \\
\hline
\end{tabular}




\begin{tabular}{|c|c|c|}
\hline & $\begin{array}{l}\text { auditing of Savings } \\
\text { And Credit Co- } \\
\text { operatives (SACCOs) }\end{array}$ & \\
\hline 2. & $\begin{array}{l}\text { Price stabilization } \\
\text { through consumer } \\
\text { cooperatives initiative }\end{array}$ & $\begin{array}{l}\text { To support development of } \\
\text { viable agricultural and } \\
\text { consumer cooperatives for } \\
\text { the distribution of quality } \\
\text { inputs and essential } \\
\text { consumer goods and } \\
\text { stabilizing prices for } \\
\text { consumer commodities }\end{array}$ \\
\hline 3. & $\begin{array}{l}\text { Promoting sustainable } \\
\text { production and } \\
\text { commodity trading in } \\
\text { cooperatives using } \\
\text { FARMIS( farmer } \\
\text { records management } \\
\text { information system) }\end{array}$ & $\begin{array}{l}\text { To empower cooperative } \\
\text { societies by creating a new } \\
\text { member service program }\end{array}$ \\
\hline 4. & $\begin{array}{l}\text { Cooperative Data } \\
\text { Analysis } \\
\text { System(CODAS) } \\
\text { implementation }\end{array}$ & $\begin{array}{l}\text { To develop data base for } \\
\text { collation and analysis of data } \\
\text { on all forms of cooperatives } \\
\text { in Uganda to enhance the } \\
\text { understanding of the } \\
\text { constraints and potential of } \\
\text { any particular and important } \\
\text { segment of the cooperative } \\
\text { sector that would facilitate } \\
\text { planning for and } \\
\text { interventions in the sector. }\end{array}$ \\
\hline 5. & $\begin{array}{l}\text { Improving } \\
\text { professionalism in } \\
\text { cooperatives } \\
\text { management }\end{array}$ & $\begin{array}{l}\text { To train high level } \\
\text { professionals to } \\
\text { competitively manage } \\
\text { cooperative enterprises into } \\
\text { highly successful and } \\
\text { productive corporate bodies }\end{array}$ \\
\hline 6. & $\begin{array}{l}\text { Income Smoothening } \\
\text { Through Warehouse } \\
\text { Receipt System }\end{array}$ & $\begin{array}{l}\text { To smoothen small holder } \\
\text { farmers' incomes by building } \\
\text { an existing warehouse } \\
\text { receipt system and } \\
\text { strengthening it into a } \\
\text { sustainable marketing system } \\
\text { required to improve } \\
\text { efficiency in marketing of } \\
\text { agricultural commodities } \\
\text { through cooperatives. }\end{array}$ \\
\hline
\end{tabular}

were from Kalikid and Aduas Cabanatuan City. Members' trust to the cooperatives was the top problem that challenges the operations and management of the cooperatives.

\section{RECOMMENDATIONS}

In the light of the foregoing, the researcher suggests that:

1. The management of the Cooperatives must be careful in using their capital.

2. The members of Cooperatives should make sure that their liability must be paid in time.

3. The management and members of Cooperative must be communicating to each other.

4. The management must be willing to adapt the changes outside their control.

5. Cooperatives must have a well skilled and trained management to avoid complications and to be able to face the future problems.

\section{REFERENCES}

[1] The internal and external governance of cooperatives: effective membership and consistency of values Ermanno Tortia - Academia.edu www.academia.edu

[2] Domingo, A.V. (2018).Product, pricing and promotional strategies of Restaurants in Nueva Ecija: An Assessment. International Journal of Advanced Engineering, Management and Science(ISSN: 24541311),4(11), 753-756. http://dx.doi.org/10.22161/ijaems.4.11.2

[3] International Cooperative Alliance.Statement on the Cooperative Identity. Retrieved on: 2011-07-31.

[4] http://www.uwcc.wisc.edu/info/ocpap/groves.html

[5] http://www.uk.coop/what-co-operative. Co-operatives UK what is co-operative?

[6] http://www.hazelden.org/web/public/faqintervention.pa ge

[7] University of Wisconsin Center for Cooperatives Reflections on Cooperation and Cooperatives www.uwcc.wisc.edu

[8] University of Wisconsin Center for Cooperatives : Evolution of Cooperative Thought, Theory and Purpose www.uwcc.wisc.edu

\section{CONCLUSION}

The study revealed that the majority of the respondents are 41-50 years old, married and most of them 